IZA DP No. 9514

Colombian Emigration by Administrative Regions

Mariana Saenz

Joshua J. Lewer

November 2015 


\title{
Colombian Emigration by Administrative Regions
}

\author{
Mariana Saenz \\ Georgia Southern University
}

Joshua J. Lewer

Bradley University

and IZA

\section{Discussion Paper No. 9514 \\ November 2015}

\author{
IZA \\ P.O. Box 7240 \\ 53072 Bonn \\ Germany \\ Phone: +49-228-3894-0 \\ Fax: +49-228-3894-180 \\ E-mail: iza@iza.org
}

\begin{abstract}
Any opinions expressed here are those of the author(s) and not those of IZA. Research published in this series may include views on policy, but the institute itself takes no institutional policy positions. The IZA research network is committed to the IZA Guiding Principles of Research Integrity.

The Institute for the Study of Labor (IZA) in Bonn is a local and virtual international research center and a place of communication between science, politics and business. IZA is an independent nonprofit organization supported by Deutsche Post Foundation. The center is associated with the University of Bonn and offers a stimulating research environment through its international network, workshops and conferences, data service, project support, research visits and doctoral program. IZA engages in (i) original and internationally competitive research in all fields of labor economics, (ii) development of policy concepts, and (iii) dissemination of research results and concepts to the interested public.
\end{abstract}

IZA Discussion Papers often represent preliminary work and are circulated to encourage discussion. Citation of such a paper should account for its provisional character. A revised version may be available directly from the author. 
IZA Discussion Paper No. 9514

November 2015

\section{ABSTRACT \\ Colombian Emigration by Administrative Regions}

This article contributes to immigration literature by applying a Random Utility Maximization model to derive a migration gravity model that explains factors affecting migration outflows per administrative unit and region for the country of Colombia. Negative binomial crosssectional estimates indicate that departments sharing an international border and overall labor market conditions are significance determinants of migration patterns for the departments, but non-economic factors such as credit constraints and cultural networks also affect migration outflows. Estimation of regional migration outflows are also provided and yield unique findings per geographic location.

JEL Classification: F22, C25, H11

Keywords: emigration, Colombia, gravity model, negative binomial regression

Corresponding author:

Joshua J. Lewer

Department of Economics

Bradley University

1501 West Bradley Avenue

Peoria, IL 61625

USA

E-mail: jlewer@bradley.edu 


\section{INTRODUCTION}

Over the last half century, international migration flows have steadily risen. According to Meseguer and Burgess (2014), about 3 percent of the world's population now live in a different country than their place of birth. In order to deal with the constantly changing environment many countries need to adopt policies and create structural plans to address the benefits, problems, and social externalities created by international migration. The number of international migrants has grown by 50 percent between 1990 to 2013 (United Nations 2013). The majority of the international migration growth during the 1990 to 2013 period came from migrants moving to more developed nations with 69 percent of the growth in international migration. In comparison, developing nations only gained 31 percent of the international migration growth (United Nations 2013).

It is important for policy makers to make informed decisions based on studies of population growth, because population socioeconomic characteristics change with significant international migration. For example, Borjas (1995) reports higher levels of educational attainment and wages for U.S natives, compared to those of U.S. immigrants. In addition, he argues that greater fiscal costs of immigration are a result of a greater percentage of immigrant households receiving public assistance in comparison to native households. Specifically, Borjas (1995) reports that immigrant households' participation in public assistance are 0.1 to 1.7 percentage points higher than the participation rate of native households in public assistance between 1970 and 1990.

This paper focuses on the study of the international migration occurring for Colombia. Historically, Colombia has had negative net migration flows (Departamento Administrativo Nacional de Estadistica (DANE) 2008; Departamento Administrativo Nacional de Estadistica (DANE) 2009). According to Texido and Gurrieri (2012), Colombia has the greatest migrant outflow and the lowest inflow of any South American country. Based on the 2005 Census estimation, the number of immigrants in the country corresponds to only 
0.27 percent of Colombia's total population with the greatest inflows coming from Venezuela ${ }^{1}$, the United States, Ecuador, and Spain (Ramírez et al. 2010; Mejía Ochoa 2012).

Migration outflows have also grown over time in Colombia. The emigrant level was 391 percent higher from the period of 2000-2005 in comparison to the period of 1970-1975 (Ramírez et al. 2010). The primary factor explaining Colombia's migration outflow is a search for employment opportunities (Mejía Ochoa 2012). According to Docquier and Marfouk (2006) in 2000, Colombia was among the top 30 skilled emigration countries. This loss of the skilled population in Colombia is a classic example of "brain drain" that has been documented for many developing countries. Changes in migration flows can also affect the country's economic development. According to the World Bank's World Development Indicators, Colombia's personal remittances $^{2}$ as a percentage of the country's Gross Domestic Product (GDP) increased by approximately 40 percent from 2000 to 2005 (World Bank 2015).

The objective of this paper is to understand the characteristic of the international migration flows using the 2005 national census in an effort to identify the factors that affect Colombia's international mobility. Specifically, a model that resembles the gravity model of international migration is used to explain the factors affecting international migration flows of the different administrative regions of Colombia (also called departments). According to Ramírez et al. (2010), the Colombian areas with the greatest migration are Valle del Cauca, Bogotá, and Antioquia. Ramírez et al. (2010) also confirms that the country's departments with the greatest percentage emigrants are the departments of Risaralda, Valle del Cauca, Quindío, Putumayo, San Andres, Atlántico, Caldas, and Bogotá.

There have been many different descriptive international and internal migration studies in Colombia (Departamento Administrativo Nacional de Estadistica (DANE) 2008; Ramírez et al. 2010; Mejía Ochoa 2012; Cárdenas and Mejía 2006; Schultz 1969; Bermudez 2010; Guarnizo and Diaz 1999; Mejía et al. 2009). However, few studies have performed analytical migration studies (Fields 1979; Fields 1982; Udall 1981;

\footnotetext{
${ }^{1}$ Officially called The Bolivarian Republic of Venezuela

2 "Personal remittances comprise personal transfers and compensation of employees. Personal transfers consist of all current transfers in cash or in kind made or received by resident households to or from nonresident households.

Personal transfers thus include all current transfers between resident and nonresident individuals." (World Bank, 2015)
} 
Galvis 2002) which have focused on explaining regional characteristics of internal migration. Specifically, two studies use the gravity model of migration to explain internal migration in Colombia, in terms of the country's regional characteristics. Fields (1982) finds evidence that internal migration in Colombia is affected by regional income, distance, and education. Galvis (2002) finds that regional GDP per capita, population density, host region's security, and distance are major factors contributing to Colombia's internal migration.

This study contributes to the literature in international immigration in two ways. First, the paper provides an application of the gravity model of migration that explains the characteristics of emigration flows. Second, the analysis provides an analytical study of emigration flow in Colombia by department level. Section II of this article describes the derivation of the gravity model of migration from the Random Utility Maximization model (RUM). Section III presents the econometric estimation used to estimate the gravity model of migration. Section IV and V outline the data sources and provide detailed descriptions of the variables used in the estimation. Section VI discusses significant results, and section VII concludes by providing discussion of the results.

\section{THEORETICAL MODEL}

The theoretical foundation for the gravity model of migration for this paper is based on the Random Utility Maximization (RUM) modes described in Beine, Bertoli, and Fernández-Huertas Moraga (2015). Assume the emigration flow from the $j^{\text {th }}$ origin department to the $k^{\text {th }}$ destination country $\left(M_{j k}\right)$ is defined as,

$$
M_{j k}=p_{j k} S_{j},
$$

where $p_{j k} \in[0,1]$ is the actual share of individuals migrating from the $j^{\text {th }}$ origin department to the $k^{\text {th }}$ destination country, and $S_{j}$ is the population residing in the $j^{\text {th }}$ origin department.

In the RUM model, the utility of the $i^{\text {th }}$ individual moving from the $j^{\text {th }}$ origin department to the $k^{\text {th }}$ destination country among $\Delta$ choices is described as,

$$
U_{i j k}=w_{j k}-c_{j k}+\epsilon_{i j k},
$$


where $w_{j k}$ is the deterministic component of utility, $c_{j k}$ denotes the cost of moving from the $j^{\text {th }}$ origin department to the $k^{\text {th }}$ destination country, and $\epsilon_{i j k}$ is an error term. Assuming that the error term is independent and identically distributed as extreme value type 1 distribution then,

$$
E\left[p_{j k}\right]=\frac{e^{w_{j k}-c_{j k}}}{\sum_{l \in \Delta} e^{w_{j l}-c_{j l}}}
$$

Replacing equation (3) into equation (1) we have,

$$
E\left[M_{j k}\right]=\frac{e^{w_{j k}-c_{j k}}}{\sum_{l \in \Delta} e^{w_{j l}-c_{j l}}} S_{j}
$$

Assuming $w_{j k}$ does not vary with the $j^{\text {th }}$ origin department, equation (3) can be written to resemble the gravity model migration as,

$$
E\left[M_{j k}\right]=\phi_{j k} \frac{y_{k}}{\Omega_{j}} S_{j}
$$

where $\phi_{j k}=e^{-c_{j k}}, y_{k}=e^{w_{k}}$, and $\Omega_{j}=\sum_{l \in \Delta} y_{l} \phi_{j l}$. The empirical estimation of equation (5) requires adding an error term. Assume a well behaved error term, $\eta_{j k}$, with $E\left[\eta_{j k}\right]=1$ then equation (1) becomes,

$$
M_{j k}=\phi_{j k} \frac{y_{k}}{\Omega_{j}} S_{j} \eta_{j k}
$$

The term $\phi_{j k}=e^{-c_{j k}}$ captures the accessibility of the $k^{\text {th }}$ destination country for potential migrants from the $j^{\text {th }}$ origin department. The term $c_{j k}$ captures the cost of migrating from the $j^{\text {th }}$ department to the $k^{\text {th }}$ country, and it is modeled as the linear combination of factors believed to have a significant effect on the cost of migration. Such factors include credit constraints, time-variant factors, and time invariant factors.

The term $y_{k}=e^{w_{k}}$ captures the attractiveness of the $k^{\text {th }}$ destination country where the term $w_{k}$ is modeled as the linear combination of variables affecting the attractiveness of the destination country to migrants. The term $\Omega_{j}$ is the multilateral resistance to migration term and captures the effect that alternative destinations have on the bilateral emigration rate (Bertoli and Fernández-Huertas Moraga 2013). Anderson and Wincoop (2003) accounts for the multilateral resistance term by including the origin-dummies of the form $e^{\theta_{j} d_{j}}$, were $d_{j}$ is a dummy variable identifying the $j^{\text {th }}$ origin department and $\theta_{j}$ are the parameters to be 
estimated. Other researchers have included origin dummies and destination dummies to control for the multilateral resistance term (Ortega and Peri 2013; Beine and Parsons 2015)

\section{ECONOMETRIC ESTIMATION}

The estimation of the gravity model of migration in equation (6) is estimated using the Poisson pseudomaximum-likelihood (PPML) proposed in Santos Silva and Tenreyro (2006). The estimation of equation (6) using the PPML takes into account cases where the dependent variables $M_{j k}$ takes zero values. The PPML estimator also gives consistent estimators assuming the specification of the conditional mean is of the form $E\left(y_{i} \mid x\right)=\exp \left(x_{i} \beta\right)$.

After taking the natural log of equation (6), the conditional expectation of migration flows is defined as,

$$
\begin{array}{r}
\ln \left(E\left[M_{j k} \mid c_{j k} ; w_{k} ; S_{j} ; d_{j}\right]\right)=-c_{j k}+w_{k}+\theta_{j} d_{j}+\ln \left(S_{j}\right) \\
E\left[M_{j k} \mid c_{j k} ; w_{k} ; S_{j} ; d_{j}\right]=\exp \left(c_{j k}{ }^{\prime}+w_{k}+\theta_{j} d_{j}+\ln \left(S_{j}\right)\right)
\end{array}
$$

where $c_{j k}{ }^{\prime}=-c_{j k}$. Note that the PPML is used for count data but migration flows $M_{j k}$ is a continuous variable. The PPML estimator gives consistent estimators assuming the specification of the conditional mean is of the form $E\left(y_{i} \mid x\right)=\exp \left(x_{i} \beta\right)$ as it is specified on equation (8) (Santos Silva and Tenreyro 2006).

The gravity model of migration is estimated for the entire data set, and then by regions. Regions are departments grouped depending on their geographical location. The geographical regions are labeled Landlocked, International Border, and Coastal Border. Landlocked departments are those departments that do not share an international border or do not a coastal border. International Border departments are those departments that share an international border but do not have a coastal border. Coastal Border departments are those departments that have a coast on the Atlantic and Pacific Ocean. 
Estimation of the gravity model of migration is first estimated using the PPML using the Eicker-White robust covariance estimator (Santos Silva and Tenreyro 2006). The Pearson goodness-of-fit test for the Poisson distribution is rejected for the cross-sectional and regional regressions, suggesting than the Negative Binomial distribution is a more appropriate model to estimate emigration flows. The coefficients, the Incidence Rate Ratios (IRR), and $p$-values for the Negative Binomial Regression are reported. For the Negative Binomial the coefficients allow us to interpret the direction of the relationship between the emigration flows and the independent variables. The IRR quantifies the direction and strength a unit increase in the independent variable. ${ }^{3}$

\section{DATA}

Colombia is divided into 32 departments or administrative divisions. The data from for each of Colombia's department including emigration flows, destination country's stock of migrants, Gross Domestic Product, population, education, unemployment, government effectiveness index, and the index of basic unsatisfied necessities are taken from the national statistical system DANE (Departamento Administrativo National de Estadística). The distance between each of Colombia departments' capital and destination countries' capital is taken from Google maps. Common international border between each department and migrant's destination countries is taken from Google Earth. The common language variable is obtained from the CIA World Factbook. The unemployment rate, Gross Domestic Product, and governance indicator for the destination country are obtained from the World Bank World Economic Indicators. Destination country's capital stock is obtained from Berlemann and Wesselhöft (2014).

\footnotetext{
${ }^{3}$ For more information about derivation and interpretation of IRR see UCLA: Statistical Consulting Group (2015) and Rabe-Hesketh and Skrondal (2012).
} 


\section{DEFINTION OF THE VARIABLES}

Table 1 presents each variable used in the econometric specification and description of those variables. The cost of migrating from the $j^{\text {th }}$ department to the $k^{\text {th }}$ country, $c_{j k}$, is modeled as the linear combination of credit constraints, time-variant factors, and time-invariant factors.

The credit constraints obstruct the migrant's location choices and are controlled by an index of unsatisfied basic necessities (i.e. Necesidades Basicas Insatisfechas or NBI) at the $j^{\text {th }}$ origin department, $N B I_{j}$, and the $j^{\text {th }}$ department's government effectiveness index, gov $v_{j}$. The $N B I_{j}$ index captures household's dimensions such as economic dependency, school attendance, household structure and space, and adequate public services. The $N B I_{j}$ controls for the incidence of poverty at the $j^{\text {th }}$ origin department. Controlling for poverty at the origin location has been used to control for the role of credit constraints by Belot and Hatton (2012). The department's government effectiveness index, gov $v_{j}$, captures the regional institutional environment such as the government's ability to enforce policies, manage resources, and institution rule following frequency. The regional government effectiveness index's effect on migration varies depending on whether enforcing migration policies facilitate and impedes migration to other countries. Bauer, Lofstrom, and Zimmermann (2008) and Hatton and Williamson (2006) show that the policy of the destination country significantly effects migration patterns.

The time-variant factors that affect migration are migrant networks in the $k^{\text {th }}$ destination country, and educational level of migrants at the $j^{\text {th }}$ origin department. Migrant networks are measured by the stock of migrants from the $j^{\text {th }}$ origin department already living in the $k^{\text {th }}$ destination country and are represented by Stock $k_{j k}$. Migrant networks have been found to have a positive effect on bilateral migration (Beine, Bertoli, and Fernández-Huertas Moraga 2015). The stock of migrants is expected to have a positive effect on emigration as emigration costs decrease as the potential social network of the migrant in the destination country is larger. In other words, network effects exist; a large immigrant stock from one country will encourage more immigrants from the same country (see Kahan 1978; Murayama 1991; Rephann and Vencatasawmy 2000; Pedersen, Pytlikova, and Smith 2008; Zavodny 1997). The education level, $E d u_{j}$, is measured by the number 
of enrolled students in secondary education and it is expected to have a negative effect on bilateral migration. The bilateral migration flow is higher for low-educated migrants (Beine, Bertoli, and Fernández-Huertas Moraga 2015).

The time-invariant factors that affect migration are bilateral distance, sharing a common language, and international border. The bilateral distance , $D_{j k}$, proxies the migrant's transportation cost of emigrating and it is expected to decrease migration outflows. Sharing a common language and international border are expected to increase migration. In this paper, sharing a common language (i.e. $L A N G_{j k}$ ) and international border (i.e. Border $_{j k}$ ) also control for the multilateral resistance to migration, $\Omega_{j}$. Multilateral resistance to migration captures the heterogeneity in the migration preference and it is control by introducing origin-destination dummies for set of countries. Origin-destination dummies for the set of countries are partially controlled by the terms $L A N G_{j k}$ and Border ${ }_{j k}$. Michael Beine and Parsons (2015) also used dummies for sets of countries to control for the multilateral resistance term.

The attractiveness of the $k^{\text {th }}$ destination country, $w_{k}$, is modeled as the linear combination of relative per capita income, relative unemployment rates, destination country effectiveness, and destination country's capital stock. Relative per capita income is represented by $\frac{\text { GDPcapita }_{k}}{\text { GDPcapita }_{j}}$, where GDPcapita ${ }_{k}$ and GDPcapita are the per capita Gross Domestic Product of the $k^{\text {th }}$ destination country, and the $j^{\text {th }}$ origin department, respectively. A greater relative income per capita is expected to increase migration outflows making the destination country more attractive to migrants. The relative unemployment rate is measured by $\frac{U R_{k}}{U R_{j}}$, where $U R_{k}$ and $U R_{j}$ is the unemployment rate at the $k^{\text {th }}$ destination country, and $j^{\text {th }}$ origin department, respectively. Popular studies of immigration, such as Sjaastad (1962), Friedberg and Hunt (1995), Card (2001), and Borjas (2003) use a standard labor market model in which immigrant workers are assumed to respond to differences in wages and employment opportunities between countries. Greater employment opportunities and higher relative wages in the destination country, ceteris paribus, encourage greater immigration. Thus, the relative unemployment rate is expected to decrease migration outflows making the destination country less attractive to migrants. Lastly, the destination country's capital stock proxies availability of public services and 
infrastructure. Borjas (1999) finds evidence of "welfare magnets", given that immigrants select to pay the cost of immigration, they will tend to migrate toward the country which offers the greatest public assistance.

In summary, since the multilateral resistance term is controlled by the terms $L A N G_{j k}$ and Border $_{j k}$, expected emigration flow from the $j^{\text {th }}$ origin department to the $k^{\text {th }}$ destination country is defined as,

$$
E\left[M_{j k}\right]=e^{-c_{j k}} e^{w_{k}} S_{j},
$$

where

$$
c_{j k}=a_{1} D_{j k}+a_{2} N B I_{j}+a_{3} \operatorname{Gov}_{j}+a_{4} \operatorname{Stock}_{j k}+a_{5} E d u_{j}+a_{6} L A N G_{j k}+a_{7} \text { Border }_{j k}
$$

and

$$
w_{k}=b_{1} \frac{\text { GDPcapita }_{k}}{\text { GDPcapita }_{j}}+b_{2} \frac{U R_{k}}{U R_{j}}+b_{3} \text { Gov }_{k}+b_{4} \text { Capital }_{k}
$$

\section{RESULTS}

Table 2 and 3 shows the results of the Negative Binominal estimation of equation (9) for all the departments and groups of departments based on the geographical location. The variable $L A N G_{j k}$ is dropped out of the estimation because of its high correlation with the relative income per capita and the destination country government effectiveness variables.

The first column in Table 2 shows the Negative Binomial Estimation results for the cross-sectional analysis. Results show that sharing an international border, relative unemployment rates, the stock of migrants in the destination country, relative income per capita, and the destination country's capital stock increase Colombia's departmental emigration flows. Sharing an international border and relative unemployment rates have the largest effect on Colombian emigration flows. Departments that share an international border are expected to have a 9.73 times higher emigration rate compared to non-contiguous border sharing departments. An increase of one percentage point in the relative unemployment rate is expected to increase emigration flows by a factor of 2.78 . That is, the emigration flows are approximately three times greater for every percentage point increase in the relative unemployment rate of the destination country in relation to the source department. 
The stock of Colombian migrants in the destination country also has a significant impact on Colombia's emigration flows. Regional emigration flows are expected to increase by approximately 42 percent for every person increase in the migrant's network in the destination country. Relative income per capita also have a significant positive effect on emigration flows. For every percentage point increase in the relative income per capita of the destination country to the source country, emigration flows increase by about 4.5 percent.

Non-economic variables such as the destination country capital stock have a significant positive impact on the regional emigration flows. The positive effect of the destination country's capital stock indicates that countries with greater public assistance and infrastructure are more attractive to Colombian migrants.

Results of the cross-sectional analysis also indicate that bilateral distance, the index of unsatisfied basic necessities, and destination country's government effectiveness have a negative impact on migration outflows in Colombia. Better governance indices for the destination countries, reduces regional migration outflows. That is, for every percentage point improvement in the destination country governance, regional migration outflows are expected to decrease by close to 18 percent. The index of unsatisfied basic necessities, measured by the number of total people with basic unsatisfied necessities, is expected to decrease emigration flows by approximately 3 percent for every percentage point increase in the index. Thus, greater credit constraints measured by increasing values of the basic unsatisfied necessities index reduces emigration flows. The distance variable has the smallest economic effect on emigration flows. This can be interpreted as transportation cost not having a big impact on the migrant's decision to permanently move to another country.

Table 3 shows the Negative Binomial regional regression results. Regions were defined according to the departments' geographical location. Departments with no international and coastal border were grouped into landlocked departments. Departments sharing an international border and no coastal border were grouped in the International Border group. Lastly, departments having a coastal border with either the Pacific or Atlantic Ocean were grouped in the Coastal border group.

Across all regions changes in the relative unemployment rate have the greatest impact on migration outflows from Colombia. An increase of one percentage point in the relative unemployment rate is expected 
to increase emigration flows by a factor of 4.02 in landlocked departments, 2.71 in departments sharing an international border and no coastal border, and 2.41 percent in departments with coastal border. The stock of Colombian migrants in the destination countries and the country's regional educational level are significant across all regions. The changes in the stock of migrants in the destination country and regional educational level have different effects across the regions. Increases in the stock of migrants in other countries are expected to increase migration in those departments sharing an international and coastal border. In landlocked department the stock of migrants internationally decrease emigration flows. The level of education is also a significant factor influencing emigration, however, it has a small effect. Department's level of education affects emigration across all regions by less than 0.01 percent. Increase in human capital in landlocked departments and those sharing an international border have a negative and small impact on migration flows. In departments with coastal border, increases in education have a statistically but not economically significant increase on emigration.

Credit constraints have a significant impact on emigration flows in landlocked departments and in those departments with coastal border. For every percentage point increase in the unsatisfied basic necessities index emigration flows are expected to decrease by 26 percent and increase by 9.7 percent in landlocked departments and the coastal border group, respectively. Greater constraints in the credit market have a greater impact on those departments that are not in close proximity to another country. For the departments with a coastal border an increase in the number of people classified as poor increases emigration flows.

Noneconomic variables such as the government effectiveness of the source department and destination country indicate different results across regions. Changes in institutional environment significantly impact departments located on the coast. For every percentage increase in the regional government effectiveness, migration outflows are expected to decrease migration outflows by about 4 percent in departments located on the coast. In addition, for every percentage point increase in the destination country's government effectiveness, emigration flows are expected to increase by about 82 percent in departments located on the coast. Last, the significant positive impact of the destination country's capital stock on the migration outflows 
from landlocked departments and those located on the coast implies that the destination country's infrastructure is a significant factor on the migration's decision to locate in another country.

\section{CONCLUSION}

The Random Utility Maximization model is used to derive a migration model that resembles the gravity model to explain factors affecting migration outflows by administrative regions for the country of Colombia. Results show that departments sharing an international border have the greatest outflow of migration. Support for labor market conditions as an emigration determinant is found as relative unemployment rates have an economically significance influence in migration outflows. The results indicate that non-economic factors significantly affect the migrant's decision to migrate. Non-economic factors such as credit constraints and destination country's governance effectiveness affect significantly migration outflows for the administrative regions in Colombia. The non-economic variable with the greatest effect on Colombian emigration is the destination country's governance indicator. Improvement in the destination country's government effectiveness implies an impediment to migrants.

Estimation of regional migration outflows gives different results depending on the department's geographic location. For example, greater credit constrains decreases migration outflows from landlocked departments. However, for those departments located on the coast greater constrains increases migration outflows. This can be interpreted as those affected by constrains in the credit market being a different set of the population from those migrating. 


\section{REFERENCES}

Anderson, By James E, and Eric V a N Wincoop. 2003. "Gravity with Gravitas : A Solution to the Border Puzzle.” American Economic Review 93 (1): 170-92. doi:10.1257/000282803321455214.

Bauer, Thomas, Magnus Lofstrom, and Klaus Zimmermann. 2008. "Immigration Policy, Assimilation of Immigrants and Natives' Sentiments toward Immigrants: Evidence from 12 OECD Countries." Swedish Economic Policy Review 118: 515-843.

Beine, Michel, Simone Bertoli, and Jesús Fernández-Huertas Moraga. 2015. “A Practitioners' Guide to Gravity Models of International Migration.” The World Economy, 1-17. doi:10.1111/twec.12265.

Beine, Michel, and Christopher Parsons. 2015. "Climatic Factors as Determinants of International Migration.” The Scandinavian Journal of Economics 117 (2): 723-67. doi:10.1111/sjoe.12098.

Belot, Michèle V K, and Timothy J. Hatton. 2012. “Immigrant Selection in the OECD.” Scandinavian Journal of Economics 114 (4): 1105-28. doi:10.1111/j.1467-9442.2012.01721.x.

Berlemann, Michael, and Jan-Erik Wesselhöft. 2014. "Estimating Aggregate Capital Stocks Using the Perpetual Inventory Method - New Empirical Evidence for 103 Countries." Review of Economics 65: $1-34$.

Bermudez, Anastasia. 2010. “The Transnational Political Practices of Colombians in Spain and the United Kingdom: Politics 'here' and 'there.”' Ethnic and Racial Studies 33 (1): 75-91. doi:10.1080/01419870903125838.

Bertoli, Simone, and Jesús Fernández-Huertas Moraga. 2013. "Multilateral Resistance to Migration.” Journal of Development Economics 102. Elsevier B.V.: 79-100. doi:10.1016/j.jdeveco.2012.12.001.

Borjas, George J. 1995. “The Economic Benefits from Immigration.” Journal of Economic Perspectives 9 (2): 3-22. 
1999. “Immigration and Welfare Magnets.” Journal of Labor Economics 17 (4): 607-37. doi:10.1086/209933.

2003. “The Labor Demand Curve.” Quarterly Journal of Economics 118 (4): 1335-74.

Card, David. 2001. “Immigrant Inflows, Native Outflows, and the Local Labor Market Impacts of Higher Immigration.” Journal of Labor Economics 19 (1): 22-64. doi:10.1086/209979.

Cárdenas, Mauricio, and Carolina Mejía. 2006. "Migraciones Internacionales En Colombia : ¿ Qué Sabemos ?" Working Papers Series, no. 30. http://www.fedesarrollo.org.co/wpcontent/uploads/2011/08/WP-No.-30-Migraciones-internacionales-en-Colombia.pdf.

Departamento Administrativo Nacional de Estadistica (DANE). 2008. "Estimation de La Migracion 19732005." Estudios Postcensales 6.

—. 2009. "Projectiones Nacionales Y Departamentales de Poblacion 2005-2020.” Estudioes Postcensales 7.

Docquier, Frédéric, and Abdeslam Marfouk. 2006. "International Migration by Educational Attainment (1990-2000)." In International Migration, Remittances, and the Brain Drain, edited by Caglar Ozden and Maurice Schiff, 151-200. New York: Palgrave Macmillan.

Fields, Gary S. 1979. "Lifetime Migration in Colombia : Tests of the Expected Income Hypothesis." Population and Development Review 5 (2): 247-65.

1982. "Place-to-Place Migration in Colombia." Economic Development and Cultural Change 30 (3): 539. doi:10.1086/452575.

Friedberg, Rachel M, and Jennifer Hunt. 1995. “The Impact of Immigrants on Host Country Wages, Employment and Growth.” Journal of Economic Perspectives 9 (2): 23-44. doi:10.1257/jep.9.2.23.

Galvis, Aponte Luis. 2002. "Determinantes de La Migración Interdepartamental En Colombia, 1988-1993." Documentos de Trabajo Sobre Economia Regional 5 (29): 1-45. 
Guarnizo, Luis Eduardo, and Luz Marina Diaz. 1999. "Transnational Migration: A View from Colombia.” Ethnic and Racial Studies 22 (2): 397-421. doi:10.1080/014198799329530.

Hatton, Timothy J., and Jeffrey G. Williamson. 2006. Refugees, Asylum Seekers, and Policy in Europe. Edited by Rolf J. Langhammer and Federico Foders. Labor Mobility and the World Economy. Heidelberg, Germany: Springer.

Kahan, Arcadius. 1978. “Economic Opportunities and Some Pilgrims' Progress: Jewish Immigrants from Eastern Europe in the U.S., 1890-1914.” The Journal of Economic History 38 (1): 235-51.

Mejía Ochoa, William. 2012. “Colombia Y Las Migraciones Internacionales . Evolución Reciente Y Panorama Actual a Partir De Las Cifras.” Revista Interdisciplinar Da Mobilinterdisciplinar Da Mobilidade Humna 20 (39): 185-210. http://www.scielo.br/pdf/remhu/v20n39/v20n39a10.pdf.

Mejía, William, Diana Ortiz, Claudia B Puerta, Jackeline Mena, and Martha E Diaz. 2009. "Nacional Encuesta: 2008-2009. Resultados Generales de Migraciones Internacionales Y Remesas.”

Meseguer, Covadonga, and Katrina Burgess. 2014. "International Migration and Home Country Politics.” Studies in Comparative International Development, no. February: 1-12. doi:10.1007/s12116-014-9149-z.

Murayama, Yuzo. 1991. "Information and Emigrants: Interprefectural Differences of Japanese Emigration to the Pacific Northwest, 1880-1915.” The Journal of Economic History 51 (1): 125-47. doi:10.1017/S0022050700038390.

Ortega, Francesc, and Giovanni Peri. 2013. "The Effect of Income and Immigration Policies on International Migration.” Migration Studies 1 (1): 1-35. doi:10.1093/migration/mns004.

Pedersen, Peder J., Mariola Pytlikova, and Nina Smith. 2008. Selection and Network effects-Migration Flows into OECD Countries 1990-2000. European Economic Review. Vol. 52. doi:10.1016/j.euroecorev.2007.12.002. 
Rabe-Hesketh, Sophia, and Anders Skrondal. 2012. Multilevel and Longitudinal Modeling Using Stata.

Volume II: Categoriacal Responses, Counts, and Survival. Third. College Station, TX: Stata Press.

Ramírez, Clemencia, Marcela Zuluaga, and Clara Perilla. 2010. "Perfil Migratorio de Colombia," 104.

Rephann, Terrance J., and Coomaren P. Vencatasawmy. 2000. "Determinants of the Spatial Mobility of Immigrants in Sweden.” The Review of Regional Studies 30 (2): 189-213.

Santos Silva, Joao, and Silvana Tenreyro. 2006. "The Log of Gravity." The Review of Economics and Statistics 88 (4): 641-58. doi:10.1162/rest.88.4.641.

Schultz, T Paul. 1969. "Population Growth and Internal Migration in Colombia,”x, 1041.

Sjaastad, Larry A. 1962. “Journal of Political Economy,.” Journal of Political Economy, 70 (5): 80-93.

Texido, Ezequiel, and Jorge Gurrieri. 2012. "Panorama Migratorio de América Del Sur."

UCLA: Statistical Consulting Group. 2015. "Stata Annotated Output. Negative Binomial Regression." http://www.ats.ucla.edu/stat/stata/output/stata_nbreg_output.htm.

Udall, Alan T. 1981. "Transport Improvements and Rural Outmigration in Colombia.” Economic Development and Cultural Change 29 (3): 613. doi:10.1086/451274.

United Nations. 2013. "International Migration Report.” Journal of Ethnic and Migration Studies. doi:10.1080/1369183X.1995.9976503

World Bank. 2015. "World Development Indicators." http://databank.worldbank.org/data/views/reports/tableview.aspx.

Zavodny, Madeline. 1997. "Welfare and the Locational Choices of New Immigrants." Economic Review. 


\section{APPENDIX}

Table 1. Descriptive Statistics

\begin{tabular}{|c|c|c|c|}
\hline Variable & Description & Mean & Std. Dev \\
\hline $\mathbf{M}_{\mathbf{j k}}$ & $\begin{array}{l}\text { Migration from source department to destination country } \\
(2005)\end{array}$ & 506.157 & 1932.271 \\
\hline Dist $_{j k}$ & $\begin{array}{l}\text { Distance between source department's capital and } \\
\text { destination country's capital (in kilometers) }\end{array}$ & 3847.804 & 3933.779 \\
\hline $\mathbf{N B I}_{\mathbf{j}}$ & $\begin{array}{l}\text { Percentage of people with a least one basic necessity } \\
\text { unsatisfied in the source department }\end{array}$ & 38.19379 & 16.66982 \\
\hline Govj & $\begin{array}{l}\text { Percentage of government employees in the source } \\
\text { department who gave a favorable rating to government } \\
\text { entities on: disposition to follow rules, enforce policies and } \\
\text { manage resources according to their institutional mission }\end{array}$ & 67.77879 & 8.222551 \\
\hline Stock $_{\mathbf{j k}}$ & $\begin{array}{l}\text { Migration from source department to destination country } \\
\text { before } 1996 \text { according to the } 2005 \text { Colombian Census }\end{array}$ & 0.6045304 & 2.489101 \\
\hline $\mathbf{E d u}_{\mathbf{j}}$ & $\begin{array}{l}\text { Number of enrolled students in private and public secondary } \\
\text { education in the source department }\end{array}$ & 115774.8 & 140618.8 \\
\hline Border $_{j k}$ & $\begin{array}{l}\text { Source destination department has an international border } \\
(=1)\end{array}$ & 0.0330579 & 0.1790344 \\
\hline Lang $_{j k}$ & $\begin{array}{l}\text { Common dominant language between source department } \\
\text { and destination country }(=1)\end{array}$ & 0.7272727 & 0.4459765 \\
\hline Relativeykj & $\begin{array}{l}\text { Ratio of destination country Gross Domestic Product ( } 2005 \\
\text { USD) to source department Gross Domestic Product (2005 } \\
\text { USD; trillions) }\end{array}$ & 7.152979 & 8.924506 \\
\hline Relativeur $_{\mathbf{k j}}$ & $\begin{array}{l}\text { Ratio of destination country unemployment rate (2004) to } \\
\text { source country unemployment rate (2004) }\end{array}$ & 0.8378189 & 0.7516026 \\
\hline Govk & $\begin{array}{l}\text { Destination country government effectiveness (range value - } \\
2.5 \text { (weak) to } 2.5 \text { (strong) government performance }\end{array}$ & 0.3527273 & 1.064662 \\
\hline Capital $_{k}$ & $\begin{array}{l}\text { Destination country capital stock in } 2005 \text { (constant } 2000 \\
\text { USD) }\end{array}$ & 3.138263 & 7.375314 \\
\hline $\mathbf{S}_{\mathbf{j}}$ & Population in source department (2005) & 1299654 & 1525123 \\
\hline
\end{tabular}


Table 2. Negative Binomial Regression of Emigration

\begin{tabular}{|c|c|c|c|}
\hline & Coeff & IRR $^{1}$ & p-value \\
\hline Dist $_{\mathbf{j k}}{ }^{*}$ & -0.0002 & 0.9998 & $<0.001$ \\
\hline $\mathrm{NBI}_{\mathbf{j}}{ }^{*}$ & -0.032 & 0.9682 & $<0.001$ \\
\hline Gov $_{\mathbf{j}}$ & 0.012 & 1.0121 & 0.135 \\
\hline Stock $_{\mathbf{j k}} *$ & 0.354 & 1.4245 & $<0.001$ \\
\hline $\mathbf{E d u}_{\mathbf{j}}$ & -0.0000001 & 1.0000 & 0.833 \\
\hline Border jk* $^{*}$ & 2.276 & 9.7375 & $<0.001$ \\
\hline Relativeykj* $_{\text {kj }}$ & 0.044 & 1.0454 & 0.002 \\
\hline Relativeurkj* & 1.024 & 2.7833 & $<0.001$ \\
\hline $\operatorname{Gov}_{\mathbf{k}} * * *$ & -0.196 & 0.8220 & 0.070 \\
\hline Capital $_{k} *$ & 0.042 & 1.0428 & 0.006 \\
\hline $\ln \left(S_{j}\right)^{*}$ & 0.912 & 2.4884 & $<0.001$ \\
\hline
\end{tabular}

$*, * *, * * *$ indicates significant effects at the $1 \%, 5 \%$, and $10 \%$ level, respectively. $\mathrm{N}=363$.

IRR is the Incidence Rate Ratio. IRR $=e^{- \text {Coeff }}$ where Coeff is the estimated coefficient of the Negative Binomial regression. 
Table 3. Negative Binomial Regression of Regional Emigration

\begin{tabular}{|c|c|c|c|c|c|c|c|c|c|}
\hline & \multicolumn{3}{|c|}{ Landlocked } & \multicolumn{3}{|c|}{ International Border } & \multicolumn{3}{|c|}{$\begin{array}{l}\text { Coastal Border (Atlantic and } \\
\text { Pacific Coastal Border) }\end{array}$} \\
\hline & Coeff. & IRR & p-value & Coeff. & IRR & p-value & Coeff. & IRR & p-value \\
\hline Dist $_{\mathbf{j k}}$ & $-0.0002 *$ & 0.9998 & 0.005 & -0.0001 & 0.9999 & 0.156 & $-0.0002 *$ & 0.9998 & $<0.001$ \\
\hline $\mathbf{N B I}_{\mathbf{j}}$ & $-0.306^{*}$ & 0.7366 & $<0.001$ & -0.042 & 0.9590 & 0.248 & $0.093^{*}$ & 1.0973 & $<0.001$ \\
\hline Govj $_{j}$ & -0.030 & 0.9702 & 0.596 & 0.006 & 1.0061 & 0.769 & $-0.045^{* * *}$ & 0.9558 & 0.074 \\
\hline Stock $_{\mathbf{j k}}$ & $-0.159 * *$ & 0.8529 & 0.041 & $0.554 *$ & 1.7396 & 0.005 & $0.550^{*}$ & 1.7329 & $<0.001$ \\
\hline $\mathbf{E d u}_{\mathbf{j}}$ & $-0.00005^{*}$ & 0.999 & $<0.001$ & $-0.00005^{*}$ & 0.999 & $<0.001$ & $0.00001^{*}$ & 1.000014 & 0.001 \\
\hline Relativeykj & 0.039 & 1.0394 & 0.381 & 0.011 & 1.0106 & 0.873 & -0.067 & 0.9354 & 0.160 \\
\hline Relativeur $_{\mathbf{k j}}$ & $1.392 *$ & 4.0237 & $<0.001$ & 0.997* & 2.7108 & 0.003 & $0.882 *$ & 2.4146 & $<0.001$ \\
\hline Govk $_{k}$ & -0.219 & 0.8032 & 0.358 & -0.300 & 0.7406 & 0.464 & $0.598 * * *$ & 1.8177 & 0.083 \\
\hline Capitalk & $0.065^{* *}$ & 1.0670 & 0.013 & 0.052 & 1.0533 & 0.161 & $0.067 * * *$ & 1.0688 & 0.07 \\
\hline $\ln \left(S_{j}\right)$ & $3.399 *$ & 29.9261 & $<0.001$ & $1.699 *$ & 5.4699 & 0.001 & $0.480 * * *$ & 1.6159 & 0.099 \\
\hline
\end{tabular}

$*, * *, * * *$ indicates significant effects at the $1 \%, 5 \%$, and $10 \%$ level, respectively

IRR is the Incidence Rate Ratio. IRR $=e^{- \text {Coeff }}$ where Coeff is the estimated coefficient of the Negative Binomial regression Landlocked departments: Risaralda, Caldas, Quindío, Huila, Tolima, Cundinamarca, Santander, Casanare, Meta, Guaviare, Caquetá.

International Border departments: Putumayo, Vaupés, Vichada, Boyacá, Arauca, Norte de Santander, Cesar, Amazonas, Guainía.

Coastal Border departments: Cauca, Chocó, Nariño, Valle del Cauca, Atlántico, La Guajira, Magdalena, Bolívar, Córdoba, Antioquia, San Andrés, Sucre. 
Figure 1. Map of Colombia by Administrative Regions

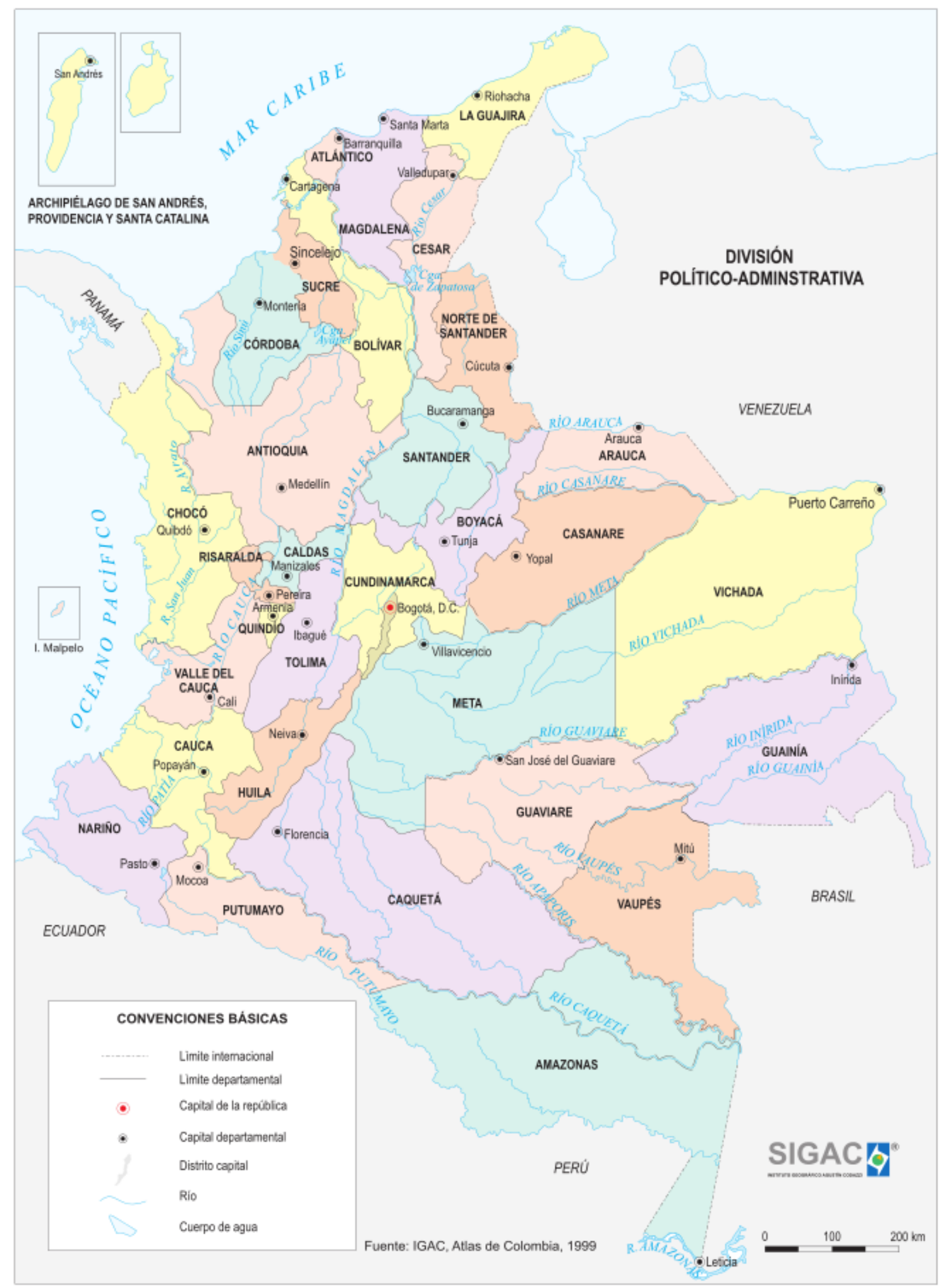

